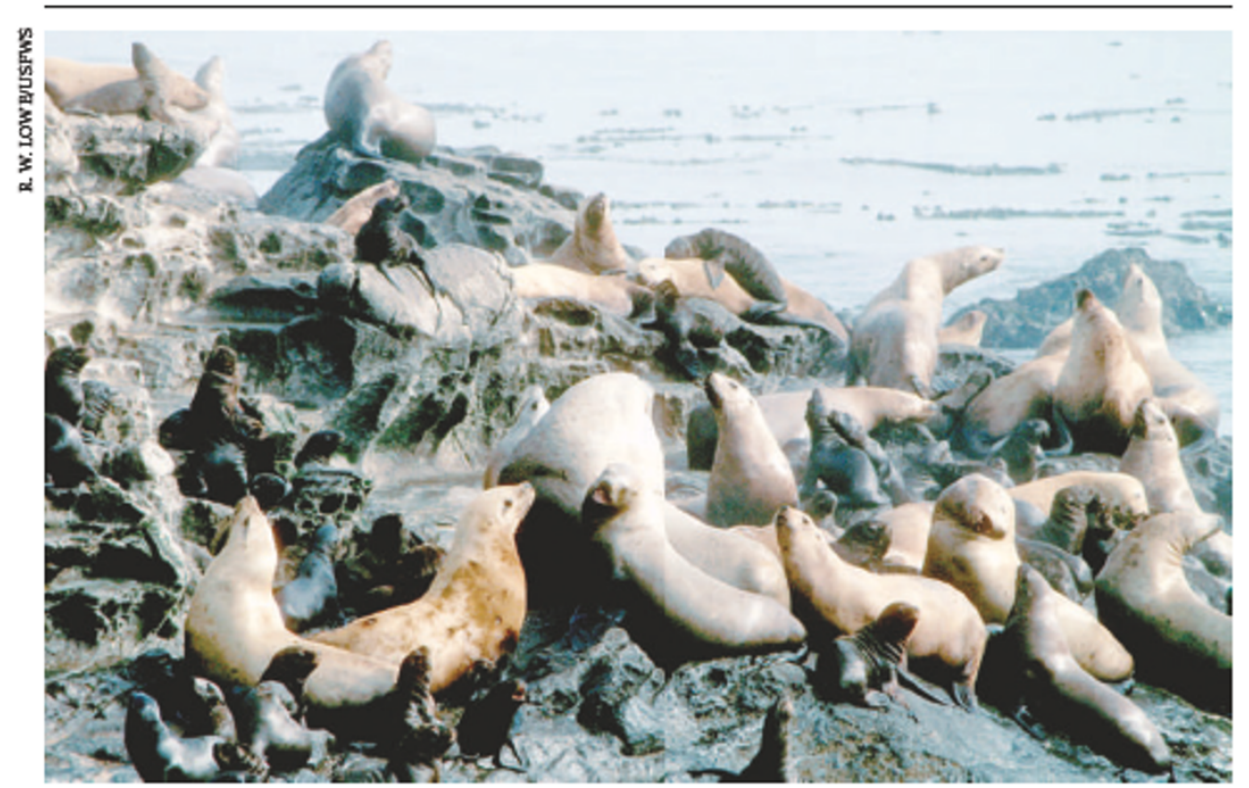

Do not disturb: Steller sea lions willenjoy a hassle-free summer

\title{
Sea-lion studies come to a halt after court judgement
}

A US federal court has shut down a research programme on the endangered Steller sea lion, ruling that studies - including the branding of pups - were inadequately monitored and could harm the animals.

The 26 May ruling scuppers the plans of groups of researchers who intended to study the sea lions (Eumetopias jubatus) this summer from Oregon to Alaska.

Last year, the Humane Society of the United States, an animal-welfare group based in Washington DC, sued the US National Marine Fisheries Service (NMFS), alleging that the agency failed to monitor and analyse studies worth more than $\$ 120$ million begun in 2001 (see Nature 436, 315; 2005). In her ruling, Judge Ellen Huvelle determined that the NMFS “ arbitrarily and capriciously ${ }^{n}$ failed to do so.

Sharon Young, the humane society's marine issues field director, says the organization sued to force the NMFS to assess the environmental impact of the research. ${ }^{\alpha}$ This lawsuit was about conducting good science by coordinating and designing valid studies," she says.

${ }^{\circ}$ We are disappointed in the ruling, but we respect it," says NMFS spokeswoman Susan Buchanan. Agency officials say they have already begun the impact assessment, which will take at least another year.

This summer, biologists planned to hot brand 2,900 Steller pups, identifying them for later observation. Air surveys and collection of blood and other samples were planned. All fieldwork is now blocked.

Kate Wynne, a biologist at the University of Alaska, is disappointed with the halt to branding, which is, she says, "a valuable tool".

Federal records that emerged during the lawsuit show that at least eight pups died after a branding expedition in 2001, which exceeds the allowed five accidental deaths. The NMFS attributed one death to that study. About 500 pups were born in the study area that year.

Roy Lowe, a refuge manager with the US Fish and Wildlife Service, says his team was worried about how many sea lions were dying. He later limited studies to alternate years, and this year turned down an NMFS request to brand and tag on the Oregon coast.

In April, the NMFS took the rare action of fining Randall Davis, a physiologist at Texas A\&M University in Galveston, $\$ 6,666$ and denying him research permits until next year. He was accused of using an unapproved anaesthetic on Alaskan Stellers and of improperly conducted studies of pups in 2003 and 2004. Davis could not be reached for comment.

${ }^{\alpha}$ Many of the scientists have themselves to blame for this," says Young. "They need to look in the mirror, and hold themselves to the same standards they hold others to."

Rex Dalton
ON THE RECORD

“I am the most loved woman in the world, the one with the smile full of mystery."

The Mona Lisaintroduces herself, thanks to a lapanese forensics expert who claims that he has recreated the sound of her voice.

\section{“Like a 300-year-old Wal-Mart on the bottom of the ocean."}

Explorer Barry Clifford describes the hugenumber of artefacts recovered from the wreck of the pirate ship Whydah off Cape Cod, Massachusetts.

Sources: Associated Press, Los Angeles Times

\section{SCORECARD}

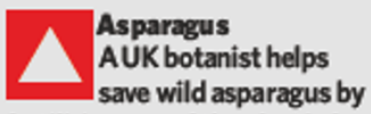
fertilizing one of the plant's few remaining females with pollen from male plants $200 \mathrm{~km}$ away.

\section{Publishingoppor tunities Bird flu gets a journal all to itself, as Blackwell} launches Influenza and Other Respiratory Viruses. For those tired of avian influenza, it will also, as advertised, cover a range of respiratory viruses. \section{Smallpox
World health officials
postpone smallpox's} doom once more, as they fail to set a date for the destruction of the last stocks of the virus.

\section{NUMBER CRUNCH}

Drinking alcohol can make you do stupid things - and for some it can mean more than just a hangover. A few facts from a recent survey of drinkers attending hospital with injuries might give you pause as you reach for your glass.

\section{$3.8 \%$ of drinking-related injuries are intentionally self-inflicted.}

$14 \%$ of drinking-related injuries are intentionally inflicted by someone else.

\section{$32.4 \%$ of drinking-related} injuries result from falling or tripping themost common source of harm. 